\title{
A Discussion on the Archive Management Model in Colleges Based on the Information Resource Sharing
}

\author{
Yan Fang \\ Qilu Normal University, Jinan City, Shandong Province, 250013, China
}

Keywords: information resources; sharing; college archives; management model

\begin{abstract}
As one of management institutions with the most abundant information resources, the breadth and depth of information resources of archive centers in colleges is incomparable, which cannot be matched by many information resource management agencies. Under the current situation in which the demand for social information resources is increasing, some colleges and universities have gradually changed the concept of serving teachers and students in the past and carried out information sharing of archive resources to serve the society. Based on the author's learning and practical experience, this paper first analyzed the necessity of information sharing in college digital archives, and then put forward the methods to realize social value of archive information resources in colleges.
\end{abstract}

\section{Introduction}

In recent years, with the increasing demand for information resources, the sharing of information resources has become a major trend in the development of information-based society. Under this situation, digital archive management models based on information sharing have emerged at the right moment. Digital archives in colleges and universities play an important role in the development of the school and also play a part in promoting social development as an important part of social information resources. How to effectively integrate and manage digital archives in colleges and maximize the value of information resources is an important topic for the ongoing research and practice of archive management departments in colleges.

\section{The Necessity of Information Sharing in College Digital Archives}

\subsection{Objective requirements for advancing China's informatization construction}

In recent years, China has vigorously promoted the pace of informatization construction. As an important part of social resources, the value of information resources can stimulate the development of social material resources and energy resources to a certain extent to realize the strategic goal of industrialization driven by information technology. As a gathering place for a large number of achievements in teaching and scientific research, colleges and universities contain great academic value. The opening and sharing of digital archives in colleges and universities can expand development and use scope of college information resources and can provide richer and more valuable resources for social development to vigorously promote the development of social information construction.

\subsection{The actual needs of the development of colleges}

The realization of archives information resources sharing in colleges promotes the formation of a situation in which resources are communicated and shared among universities. It is of great significance to improve the level of higher education in China and enhance the level of public information services. Sharing of digital archives in colleges is an important part of the construction of social public information services in China. Information sharing can give full play to the value of archive information resources in all colleges and make their respective advantages complementary to each other. It will greatly improve scientific research ability and teaching level of colleges with 
low expenditures and promote the common development and progress of colleges and universities. This is the inherent requirement for the development and reform of higher education.

\subsection{Safeguarding the public's right to know}

Today, people cannot work and live without all kinds of information data. They gradually realize the importance of information data and their demand for information resources is also increasing. Because of the wide range, authenticity, and originality of the data and files recorded in digital archives in colleges and universities, it can satisfy people's requirements for information right to a large extent. In the past, digital archive information in colleges mostly served teachers, students and graduates. In the current network technology environment, the file information in colleges is mutually connected and shared, and the demand for information resources of the public can be satisfied with powerful network. This is not only conducive to the improvement of quality and level of public services for colleges archives, but also to the protection of file users' right to information to a large extent.

\section{The path to realize the social value of archive information resources in colleges}

\subsection{The realization and development of diversified methods of archive information services}

The social value of archive information resources in colleges needs to be realized in the process of extensive social sharing and use. However, the extensive sharing and use of these resources requires archive management institutions in colleges and universities to provide diversified services. The author believes that college archive management departments should follow three methods:

First is to innovate providing and using services of archives and highlight the role of the network. To provide archives information services through the website is currently the main method for colleges currently and in future. To innovate providing and using services of archives is to seize the advantages of the website in information dissemination and exchange, and develop rich network file information services relying on the website, such as online file browsing, real-time communication, long-distance transmission and data inspection.

Second is to expand the coverage of archive information resources in colleges and actively promote the social functions of characteristic archives resources in colleges. colleges should continue to expand the scope of archives on the basis of the eleven types of archives stipulated in the "Administrative Measures for the Archives in Colleges and Universities", especially for characteristic archives resources in colleges, such as outstanding teaching achievements, important academic papers, scientific research projects, monographs and award-winning achievements. These must be covered in the archives departments. Under the premise of improving the level of its management, archive management agencies should win the trust of researchers. At the same time, relevant departments should make extensive publicity on characteristic archive resources in colleges through internal and external channels to expand the social influence of archive information resources and realize its social value.

Third is to build a platform for information exchange between universities, government agencies, enterprises, institutions and non-governmental organizations, and actively push archive information services. Archive centers in colleges should make full use of their own information and technological advantages, and unite with other functional departments in colleges to set up an information interaction platform for universities and social organizations relying on existing portal websites. This platform is for archives management institutions to disseminate and promote archival information on technological research and development, technological innovation, patented inventions, works of authorship, research projects, and major landmark achievements in accordance with the needs of other organizations in society.

\subsection{Target location and resource optimization of archive information resource integration in colleges}

There are a large number of diversified archives information resources in colleges and 
universities. If the archive information resources in colleges and universities are integrated according to the integration way in comprehensive archives centers, it will inevitably lead to high integration costs, multiple objectives and management risks. Therefore, on the basis of possessing larger collections, the archive management institutions in colleges and universities reorient the goals of the integration of archive information resources from four aspects, including resource integration objects, utilization subjects, resource construction plans and management evaluation. Archive management institutions in universities need to specify what kinds of the files are that they will integrate. This requires the file management staff to conduct in-depth research on the value of library resources, user demand and follow-up development space and identify the advantages and features of the school's collection resources. In particular, they should determine the influence of archives that need to be integrated have on the society and who are the targeted audience groups so as to design the integration plan of archive information resources. The scheme of resource integration is mainly focused on the adjustment and optimization of archive information resource institutions. The important thing is that college archive centers should be free from the concept that they serve colleges and universities and establish the idea that the center needs to serve colleges and the society.

Open classes in American colleges and universities that once swept the entire Chinese network have seized the attention of domestic high-quality educational resources to colleges and universities abroad. All this must own to the fact that the archive management agencies of prestigious schools in the United States have recorded the courses of some college teachers as sharing teaching files and disseminated them through the school education website and American college curriculum alliance platform. It can be said that this is a good example of the integration and optimization of high-quality archive resources in colleges and universities and a successful socialized case. According to relevant reports, Harvard University Archives Center is preparing to invest 50 million U.S. dollars for each of the senior professors to record the entire course, archive it, and establish a dedicated website to promote these videos. It can be said that the orientation of resource integration and optimization and the systematic optimization of teaching archive resources are the key to the success of open classes in American colleges and universities. This is also worth learning by the archive management institutions in China.

\subsection{The establishment and implementation of the archives union mechanism in colleges}

The cognitive transformation of archives resources from exclusive one to sharing one is not to force the archive management institutions in universities to achieve the socialization of archive information resource services, but to encourage them to take the socialized road gradually. After all, the socialized service and realization of the social value of archives information resources is an inevitable trend in the development of archive work in colleges and universities in the future. However, there still exists a reality that the conditions for realizing archive social value in China's colleges are relatively weak, including the problems in their own functions, resource integration methods, service marketing ways and feedback evaluation systems. Therefore, the archive management institutions in universities must seek a way to achieve coordinated development by making up for their deficiencies and solve the current problems by cooperation.

Judging from the horizontal cooperation relationship, China lacks the tradition of cooperation and development between archives centers, museums and libraries. As a result, archive centers, libraries and museums in China's universities just management themselves. Because there are obvious differences between them in terms of service objects, collection resources and functional orientation. There are only a handful of universities in China combine archives centers, museums and libraries. Therefore, it is difficult to realize the integration of archive centers, museums and libraries as Harvard University in the near future to service the public jointly. From the perspective of vertical collaboration, the establishment of archive work alliances in colleges and universities is the only way for colleges and universities to bring out the overall advantages of archive resources and serve the society in the future. At present, most of China's college archives are independently operated and self-reliant. The self-management thinking has always kept archive centers indulged in 
their own resources, so they cannot conduct social service quickly. The purpose of establishing a college archive union is to establish a collaborative relationship between archive management institutions in universities and colleges. The union can jointly develop high-quality archives information resources in colleges and universities, plan the regional archives socialization service network and create archive and information exchanges platform in colleges and universities, so that the archive information resources in colleges and universities can form a network, covering all aspects of the development of social practice. This is conducive to the realization of the social value of archive information resources in colleges and universities.

\section{Conclusions}

With the ever-increasing demand for information in the society, sharing information resources has become the general trend of the information-based society. As the main component of social information resources, digital archives in colleges need to take the initiative to shoulder the responsibility of serving the society and to actively build a digital file management model based on information sharing, so that archive information resources in colleges and universities can serve the school teaching, scientific research and management, and also can provide the public with an effective archive information service, so that the potential value of archive information resources in colleges can be fully realized.

\section{References}

[1] Jin Xiaohui. A Research on the Construction of Archive Management in Colleges under Background of Cloud Computing [J]. China Management Informatization, 2017, (15): 135-136.

[2] Liu Qi. A Research on Archive Management Model under the Background of Digital Campus [D]. Zhengzhou University Aeronautics, 2017.

[3] Zou Fan. A Research on the Construction of Network Archive Management in Colleges under the Background of "Internet Plus" [J]. Lantai World, 2016, (13): 44-46.

[4] Liang Hongwei. A Research on the Optimization of Archive Information Sharing in Traditional Universities [J]. Lantai World, 2014, (05): 38-39.

[5] Lin Shifeng. A Research on Archive Management Construction in Colleges under the Background of Informationization [J]. Reform and Opening, 2013, (15): 90-91.

[6] Yu Shoucai. A Research on the Archive Management Model in Colleges Based on IRM [J]. Journal of Chongqing University of Arts and Sciences (Natural Science Edition), 2009, (04):105-107.

[7] Qiao Li. A Preliminary Research on the Innovation of Archive Management in Colleges Based on the Modern Information Resources Sharing[J]. Lantai World, 2008, (18):49-50. 